\title{
Description of Coutieralpheus setirostris, new genus, new species, an infaunal alpheid shrimp (Crustacea: Decapoda) from Florida, U.S.A.
}

Arthur Anker* and Darryl L. Felder**

\begin{abstract}
Coutieralpheus, new genus, is established for $C$. setirostris, new species, on the basis of two specimens, a complete male and an incomplete female, collected from burrows on the tidal flats bordering Fort Pierce Inlet on the Atlantic coast of Florida, U.S.A. The new genus belongs to a large group of alpheid genera characterized by the presence of a posteroventral articulated plate on the sixth abdominal pleuron. The holotype male bears robust, subsymmetrical and equal-sized chelipeds. The mesial side of the cheliped carpus bears several rows of short setae, which are present in only three other, non-related alpheid genera. The two thickened terminal setae on the rostrum are also diagnostic. Coutieralpheus appears to combine primitive and highly evolved features and is presumably related to the monotypic genus Deioneus Dworschak, Anker \& Abed-Navandi from the Eastern Atlantic. However, in some characters the new genus also resembles the genera Salmoneus Holthuis, Alpheopsis Coutière and Parabetaeus Coutière. The host of $C$. setirostris remains unknown, although both the holotype and paratype were collected from substrates richly burrowed by thalassinidean shrimp, stomatopods, and large polychaetes.
\end{abstract}

\section{Introduction}

Infaunal alpheid shrimps have been objects of numerous taxonomic and ecological studies that reveal their surprisingly high morphological and phylogenetic diversity. Twelve alpheid genera (Leptalpheus Williams, 1965 (s. 1.), Fenneralpheus Felder \& Manning, 1986, Amphibetaeus Coutière, 1896, Salmoneus Holthuis, 1955, Deioneus Dworschak, Anker \& Abed-Navandi, 2000, Orygmalpheus De Grave \& Anker, 2000, Betaeus Dana, 1852, Athanas Leach, 1814, Athanopsis Coutière, 1897, Stenalpheops Miya, 1997 (= Chelomalpheus Kim, 1998, = Cavipelta Hayashi, 1998), Automate de Man, 1888 and Alpheus Fabricius, 1798) include about 20 species reported as obligate or facultative associates of burrowing animals such as thalassinidean mudshrimps, larger burrowing alpheids, crabs, stomatopods, echiurans, acorn worms, mud gobies and mudskippers (e.g., Coutière, 1899; Schmitt, 1926; Hart, 1964; Williams, 1965; Dawson, 1967; Saloman, 1971; Chace \& Abbott, 1980; Miya, 1980, 1984; Felder \& Manning, 1986; Berggren, 1991; Branch et al., 1994; Felder et al., 1995, 2003; De Grave \& Wilkins, 1997; Felder \& Manning, 1997; Froglia \& Atkinson, 1998; Hayashi, 1998, 2002; Dworschak \& Coelho, 1999; Dworschak et al., 2000; De Grave \& Anker, 2000; Nomura, 2000; Anker et al., 2001; Anker, 2003a; Silliman et al., 2003; Itani, pers. comm.; Anker, pers. obs.).

Shallow marine waters of southern Florida harbor a rich assemblage of infaunal alpheids, with three described species, Leptalpheus forceps Williams, 1965, Fenneralpheus chacei Felder \& Manning, 1986 and Salmoneus cavicolus Felder \& 
Manning, 1986 (Saloman, 1971, Felder \& Manning, 1986; Felder et al., 2003) and at least five more known but as yet undescribed species, three putatively assignable or very closely related to Leptalpheus and two assignable to Salmoneus aff. cavicolus (Felder \& Manning, 1997; Felder et al., 2003; Felder, pers. obs.; Anker, pers. obs.). In addition to the aforementioned undescribed forms is also a very peculiar undescribed alpheid collected from burrows of an unknown host on intertidal sand flats bordering Fort Pierce Inlet on the Atlantic coast of Florida. Because of the unique combination of morphological features this new species could not be assigned to any presently known genus of the family Alpheidae. This species is herewith described and placed in a new genus.

\section{Materials and Methods}

Specimens were collected by sieving sediments extracted with a bait suction pump, also termed a "yabby pump" (see Manning, 1975), that was applied to burrow openings on an tidal mudflat of the Indian River Lagoon near the Fort Pierce Inlet, St. Lucie County, Florida. Specimens were initially fixed in $10 \%$ buffered formalin solution and subsequently preserved in $70 \%$ ethanol. Drawings were made with the aid of a camera lucida, and most were based on moulted exuvia of the holotype specimen (thus avoiding the dissection of the appendages and the resulting unavoidable damage of the unique complete specimen). An alcohol based solution of Chlorazole Black E stain (Sigma Chemical Company®was used to enhance visibility of fine sutures and articulations in the integument prior to illustration. Carapace length $(\mathrm{CL})$ and the total length (TL) were measured in $\pm 0.1 \mathrm{~mm}$ with a calibrated ocular micrometer. Measurements were made along the dorsomedial line from the rostral tip to the posterior margin of the carapace $(\mathrm{CL})$, or to the posterior margin of the telson (TL). The type specimens were deposited in the collections of the National
Museum of Natural History, Smithsonian Institution, Washington D.C., U.S.A. (USNM).

\section{Taxonomy}

Alpheidae Rafinesque, 1815

Coutieralpheus, new genus

Diagnosis.-Carapace glabrous, with very finely marked anterolateral suture; branchiostegial margin of carapace without pronounced ventral lip; frontal region with rostrum bearing 2 thickened setae, orbital teeth absent; pterygostomial angle produced anteriorly, rounded; eyes completely concealed in dorsal view, partly visible in lateral and frontal view, eyestalk without anteromesial process or tubercle; antennular peduncle robust, first segment with ventromesial tooth; stylocerite short, robust, not appressed; second segment not elongated; outer antennular flagellum biramous; mandible typical for family, with incisor process bearing triangular distal teeth, molar process bearing a row of lamellae and setae, and with short 2-segmented palp; first maxilliped with caridean lobe expanded; second maxilliped with epipod elongate; third maxilliped pediform, lateral plate conspicuously elongate, subacute, terminal segment with rows of long, distally thickened setae, tip armed with 1 small subdistal spine; first pereiopods (chelipeds) enlarged, equal in size and shape, robust, carried extended; major cheliped with ischium bearing 1 spine on ventrolateral margin; merus robust, ventrally not depressed or excavated; carpus short, robust, cup-shaped, mesially with rows of setae; chela subcylindrical; palm smooth, linea impressa absent; cutting edges of fingers armed with irregular teeth, snapping mechanism absent; adhesive discs absent; second pereiopod with 5-segmented carpus; third pereiopod ischium and merus armed with spines on ventral margin, carpus unarmed; propodus armed with small spines on ventral margin, dactylus simple; fifth pereiopod with ischium and merus unarmed, propodus with well developed 
brush of setae; sixth abdominal segment with articulated plate at posterolateral angle; second male pleopod with appendix interna and appendix masculina; uropod with exopod bearing lateral spine and diaeresis, latter without particular modifications; telson with 2 pairs of dorsal spines and 2 pairs of posterolateral spines, posterior margin rounded, anal tubercles absent; gill formula typical for family: 5 pleurobranchs (P1-5), 1 arthrobranch (Mxp3), 0 podobranch, 2 lobed epipods (Mxp1-2), 5 strap-like epipods $=$ mastigobranchs $(\mathrm{Mxp} 3, \mathrm{P} 1-4), 5$ sets of setobranchs (P1-5), 3 exopods (Mxp1-3).

\section{Type species.-Coutieralpheus setirostris,} new species.

\section{Gender.-Masculine.}

Etymology.-This new genus is dedicated to Professor Henri Coutière (1869-1952), an eminent French carcinologist, for numerous contributions to the knowledge of alpheid shrimps that included a major monograph of the family Alpheidae (Coutière, 1899). Coutière was the first author to report the association of an alpheid shrimp with callianassid ghost shrimp and other burrowing animals in Djibouti.

Relationships.-See remarks under Coutieralpheus setirostris, new species.

\section{Coutieralpheus setirostris, new species} (Figs. 1-6)

Material examined.-Holotype: South margin of Fort Pierce Inlet channel, beside U.S. Highway A1A South Causeway, sparely vegetated intertidal sand flat, Indian River Lagoon, St. Lucie County, Florida, 27ํㅜㅇ $27.7^{\prime} \mathrm{N}, 80^{\circ} 18.7^{\prime} \mathrm{W}, 11$ August 1986 , collected by R. B. Manning, D. L. Felder and W. Lee, 1 male, CL $8.6 \mathrm{~mm}$, TL $21.8 \mathrm{~mm}$, USNM 1072201. Paratype: Same location, date, and collectors, 1 female, CL $4.0 \mathrm{~mm}$, TL $9.1 \mathrm{~mm}$, USNM 1072202.
Description.-Body relatively stout, slightly elongated (Fig. 1), not particularly compressed laterally, carapace and abdomen glabrous. Carapace with distinct suture proximal to base of antenna (Figs. 1, 2a). Rostrum triangular, broad at base, longer than wide, rostral carina very slight, terminus bearing 2 thick anteriorly directed setae (Fig. 2a). Orbital teeth absent (Fig. 2a, b). Pterygostomial angle protruding anteriorly, rounded (Fig. 2b). Branchiostegial margin with scant setae (Fig. 2g). Cardiac notch well developed (Fig. 2g). Eyes completely covered by carapace, not visible in dorsal view, exposed in lateral and anterior view, without anteromesial process or tubercle, cornea well developed (Fig. 2a, b). Ocellar beak not conspicuous. Epistomial sclerite with low, subacute process, without pronounced acute tooth.

Antennular peduncle stout (Fig. 2a, d), second article not much longer than first or third; stylocerite almost reaching distal margin of first article, distally acute or subacute (Fig. 2a); ventromesial carina with blade-like tooth as illustrated (Fig. 2d); lateral flagellum biramous, with shorter ramus well developed, situated at 4th segment (Fig. 2d). Antenna with basicerite bearing strong ventrolateral tooth (Fig. 2b); scaphocerite broadly oval, anterior margin of blade convex, slightly protruding beyond distolateral spine (Fig. 2a, e, f); carpocerite robust, not reaching distal margin of scaphocerite (Fig. $2 b, e)$.

Mouthparts not especially modified, typical for family. Mandible with incisor process bearing 6 teeth, third dorsal largest (Fig. 3a). Maxillule with palp bilobed, dorsal lobe with a few slender setae, ventral lobe with 1 robust seta (Fig. 3b). Maxilla with scaphognathite expanded (Fig. 3c), palp (endopod) small, not segmented. First maxilliped with caridean lobe on exopod expanded (Fig. 3d); palp (endopod) segmented. Second maxilliped with epipod elongated; propodus with fine transverse suture on mesial side (Fig. 3e). Third maxilliped relatively slender (Fig. $3 \mathrm{~g}$ ); lateral plate elongated, distally subacute 
(Fig. 3h, j); antepenultimate segment somewhat flattened, subtriangular in cross-section; terminal segment with tip subacute and armed with 1 subdistal spine (Fig. 3i); arthrobranch well developed (Fig. 3j).

First pereiopods (chelipeds) equal in size and similar (subsymmetrical) in shape, robust and carried extended (Fig. 1); ischium short, robust, ventrolateral margin with 1 spine (Fig. 4a); merus short, stout, slightly widening distally, margins unarmed (Fig. 4a); carpus stout, cup-shaped, with 2 blunt processes distally (Fig. 4a, c), with 3 rows of setae mesially (Fig. 4c, d); chela subcylindrical, smooth, palm about twice length of fingers; palm with shallow ventroproximal depression (Fig. 3a, c); linea impressa and adhesive discs absent; fingers not gaping when closed (Fig. 4b), tips strongly curved distally, crossing (Fig. 4b); cutting edges of pollex and dactylus armed with irregular teeth and bearing numerous setae, as illustrated (Fig. 4e, f); dactylus armed on only proximal 3/5 length of cutting edge, pollex armed on cutting edge except for most distal part; armature on left cheliped differing little from that on right cheliped (cf. Fig. 4e and f); cutting edges of fingers with numerous, conspicuous, regularly spaced setae along almost entire length (Fig. 4f).

Second pereiopod slender; ischium more than $1 / 2$ length of merus; carpus with 5 segments having ratio of $3: 1: 1: 1.2: 1.5$ (Fig. $5 a)$; chela simple, fingers distinctly longer than palm (Fig. 5a). Third pereiopod relatively slender; ischium bearing 2 spines on ventrolateral margin (Fig. 5b); merus about twice length of ischium and 1.8 times length of carpus, armed with 1 spine on ventrolateral margin; carpus unarmed, with small distoventral seta; propodus 1.5 times longer than carpus, ventrally with 4-5 small spines + 1 distoventral spine proximal to dactylus (Fig. 5b, c); dactylus simple, conical, slender, curved, about 0.4 length of propodus (Fig. 5b, c). Fourth pereiopod similar to third; merus armed with 1 or 2 spines. (Fig. $5 d$, e). Fifth pereiopod slightly more slender than third and fourth pereiopods (Fig. 5f); ischium unarmed; merus less than twice length of ischium and 1.3 times length of carpus, unarmed or armed with 1 spine on ventrolateral margin (Fig. 5f, h); carpus unarmed; propodus about 1.8 length of carpus, ventrally with few small spines and at least 8 rows of setae (Fig. $5 \mathrm{~g}$ ); dactylus only 0.3 times length of propodus, otherwise similar to that of third and fourth pereiopod.

Abdominal segments I-V with posterolateral angles of pleura rounded to weakly angular (Figs. 1, 2k); segment VI posteriorly with acute midlateral projection above articulated posterolateral plate (Fig. 2k); preanal plate posteriorly rounded (Fig. 21). Male first pleopod with endopod less than half length of exopod (Fig. 2h). Male second pleopod with both appendix masculina and appendix interna; appendix masculina slender, twice length of appendix interna, reaching $3 / 4$ length of endopod, distally bearing slender spines (Fig. 2i, j). Female second pleopod with appendix interna only. Telson relatively slender, slightly tapering, proximal width about 3 times median length; dorsal surface with 2 pairs of spines positioned well dorsal to lateral margin, anterior pair just posterior to mid-length and posterior pair in distal $1 / 4$ of telson length(Fig. 2o); posterior margin rounded, with 2 pairs of robust posterolateral spines, lateral shorter than mesial (Fig. 2o); anal tubercles absent. Uropods distinctly exceeding telson (Fig. 1); lateral lobe of sympodite distally forming single acute tooth (Fig. $2 \mathrm{~m}$ ); endopod subequal to exopod in length (Fig. 2m); exopod with diaeresis forming relatively straight suture between mesial margin and triangular lateral tooth(Fig. 2n); lateral spine stout, short (Fig. 2n). Gill formula as given for genus.

Size.-For the two known specimens, CL ranges from $4.0 \mathrm{~mm}$ in what is likely an immature female paratype to $8.6 \mathrm{~mm}$ in the apparently mature male holotype specimen; $\mathrm{TL}$ in these specimens ranges from $9.1 \mathrm{~mm}$ to $21.8 \mathrm{~mm}$, respectively.

Colour.-Overall whitish translucent, with faint patterning of reddish pink to pale rose orange color (Fig. 6). Colour most obvi- 
ous on abdominal somites 2-5 in posterior half of each tergite, creating faintly banded appearance on abdomen. Similar colour weakly in evidence on antennular peduncles where closely set spots produce a weakly banded appearance proximally but are more diffuse distally.

Habitat.-Specimens are known from only the type locality, which is a sandy intertidal flat immediately north of the Highway A1A South Causeway between the town of Fort Pierce and Fort Pierce Beach on the Atlantic shoreline. The habitat borders the southern margin of the Fort Pierce Inlet channel and is separated from the north shoreline of the causeway by a shallow $(1 \mathrm{~m}$ deep) channel. Upper reaches of the flat are exposed at low tide and bear a sparse cover of short sea grass, though this cover becomes denser and longer where the flat slopes to greater depths. Sediments and burrow waters were extracted from a variety of burrow openings in the course of sampling at this site, but no identifiable host was noted to have been found in the specific sample or samples from which these alpheid specimens were collected. While samples were taken during low tide, it also is uncertain as to whether the extracted sediments were taken on the crest of the flat or along the flooded margins, which were typically sampled to water depths of about $0.3 \mathrm{~m}$. Although the host of Coutieralpheus setirostris remains unknown, the flat is richly burrowed by thalassinidean shrimp, stomatopods, large polychaetes, nemerteans, bivalves and sipunculans. The single male and single small female of this new genus and species were collected on the same date from same site, and may well have occurred together in the same sample taken from the same host burrow. Only years later, after sorting and separate archival, was it recognized that they represented the same undescribed form. It is remarkable that, despite over twenty years of recurrent, concerted collecting there by one of us (DLF) and the late Raymond B. Manning, no additional specimens have been found.
Distribution.-Presently known from only intertidal substrates of the type locality near Fort Pierce Inlet on the Atlantic coast of Florida, U.S.A.

Etymology.-Specific name derived from the presence of two very characteristic, thickened terminal setae on the rostrum.

Remarks.-The paratype female, which is much smaller than the male holotype, was somewhat damaged during collection and lacks its first pereiopods. While it appears to rather closely match the holotype male in those characters that can be examined, nothing is known of possible sexual dimorphism in the chelipeds. The fine anterolateral suture of the carapace is extremely difficult to see in this specimen, but is also difficult to visualize in the holotype male without staining (though it is readily evident in the exuvia of this specimen).

The phylogenetic relationships of Coutieralpheus setirostris and the genus Coutieralpheus are not clear. Several features considered to be plesiomorphic within the family Alpheidae (Anker, pers. obs.), such as symmetrical chelipeds, a complete set of epipods on coxae of pereiopods, and the presence of a row of setae on the mesial side of the cheliped carpus, suggest that Coutieralpheus is a relatively basal alpheid genus. The new genus appears to be most closely related to the monotypic genus Deioneus. The type species of Deioneus, D. sandizelli Dworschak, Anker \& AbedNavandi, 2000, is known from only two females collected from burrows of the callianassid mudshrimps Corallianassa intesi (de Saint-Laurent \& Le Loeuff, 1979) and Neocallichirus pachydactylus (A. MilneEdwards, 1870) in the Cape Verde Islands (Dworschak et al., 2000; Abed-Navandi, $2000)$. Both genera are characterized by the following features: (1) sixth abdominal pleuron with an articulated plate; (2) broadly triangular rostrum; (3) carapace with anterolateral suture; (4) well developed arthrobranch and elongated lateral plate on the coxa of the third maxilliped; (5) complete set of straplike epipods (mastigobranchs); (6) chelipeds 


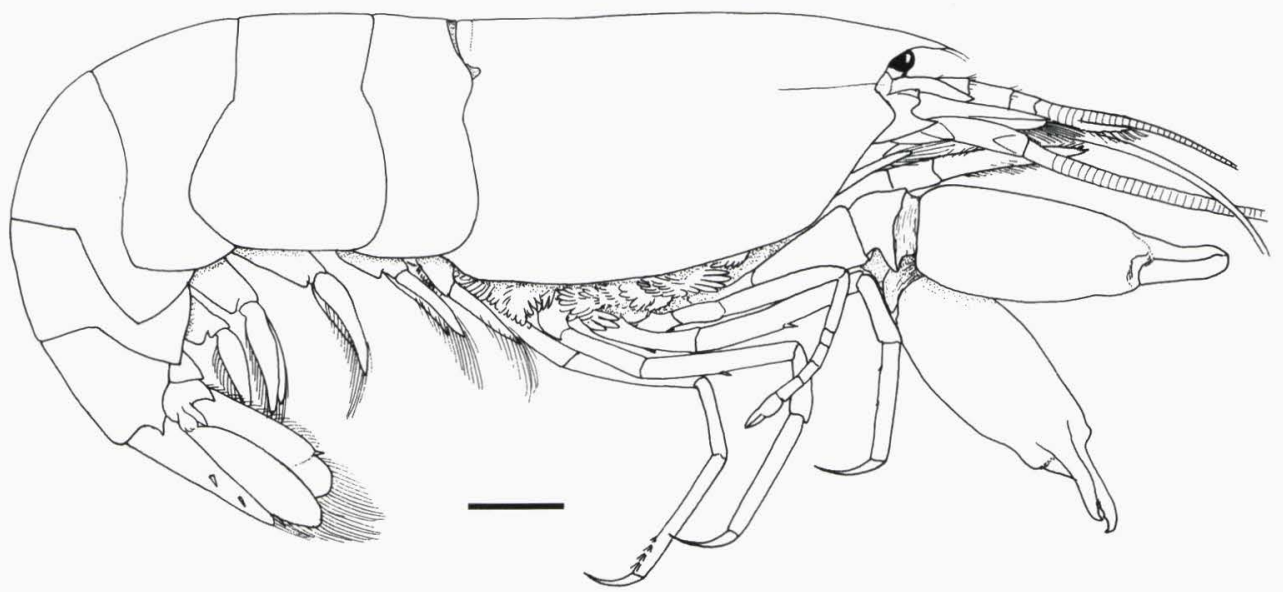

Fig. 1. Coutieralpheus setirostris, n. gen., n. sp., holotype male (USNM 1072201): habitus. Scale: $1 \mathrm{~mm}$.

subequal or equal in size; and (7) expanded caridean lobe and elongated epipod on the first and second maxillipeds, respectively. However, Coutieralpheus differs from Deioneus in many respects, including the following: (1) ischium and merus of the third and fourth pereiopods armed with spines (as compared to unarmed in D. sandizelli); (2) frontal margin lacking orbital teeth (vs. with small extra-corneal teeth in $D$. sandizelli); (3) chelipeds much more stout and carried extended (vs. more slender and carried folded in D. sandizelli); (5) merus of the chelipeds ventrally not particularly depressed (vs. ventrally excavated in D. sandizelli); (6) chelae of the chelipeds symmetrical on the two sides of the body, differing insignificantly in teeth armature (vs. very asymmetrical and differently armed in D. sandizelli); (7) carpus of the cheliped mesially bearing rows of setae (absent in D. sandizelli); (8) posterior margin of the telson broadly rounded (vs. small and truncate in D. sandizelli); (9) stylocerite short, barely reaching to the distal margin of the first article of the antennular peduncle (vs. longer, reaching to the middle of the second article in D. sandizelli); (10) rostrum bearing two thickened setae (absent in D. sandizelli) and (11) ischium of the cheliped bearing small ventrolateral spine (absent in D. sandizelli).
Deioneus is possibly also allied to Salmoneus Holthuis, 1955, at least to a small group of species with an enlarged minor cheliped (Dworschak et al., 2000). However, Coutieralpheus can be separated from all species of Salmoneus by many features. Among these, its sixth abdominal segment bears an articulated posterolateral plate (lacking in Salmoneus) and the merus on its third and fourth pereiopods is typically armed with one or two spines (unarmed in Salmoneus). It is also separated from Salmoneus by several of the same above-listed features that separate it from Deioneus (2), (3), (6), (7), (8, truncate or with median incision in Salmoneus), (9) and (10). Furthermore, the second pleopod of the female paratype does not have an appendix masculina, whereas specimens of Salmoneus, including ovigerous females, always have a well-developed appendix masculina (Carvacho, 1989; Anker, 2003b; Anker, pers. obs.). The differences between Deioneus and Leptalpheus were discussed in detail by Dworschak et al. (2000).

The new genus also shows some affinities to the genera Alpheopsis Coutière, 1896 and Parabetaeus Coutière, 1896. Alpheopsis, as presently defined (e.g., Banner \& Banner, 1973; Chace, 1988), is morphologically very heterogenous and possibly not a mono- 


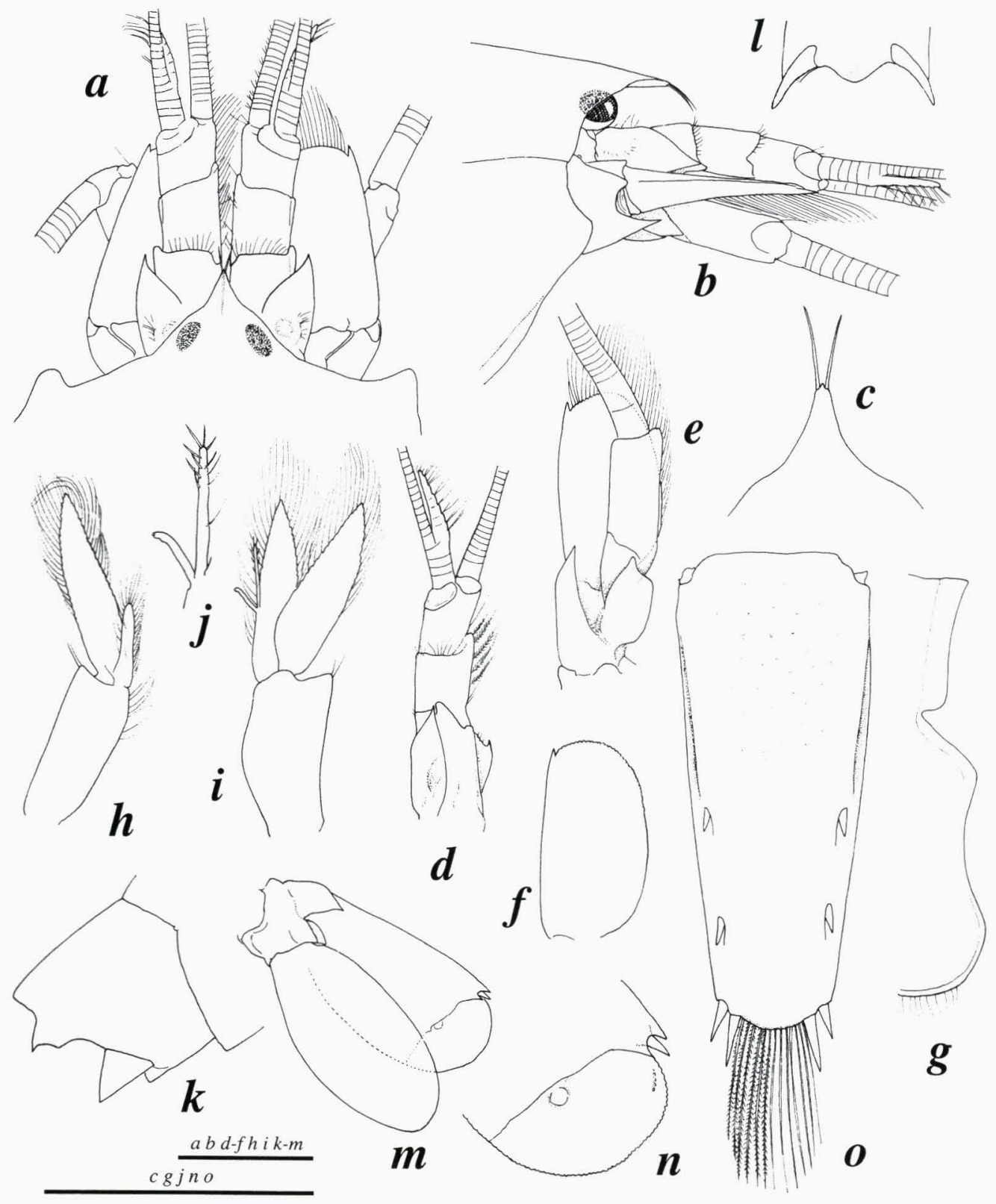

Fig. 2. Coutieralpheus setirostris, n. gen., n. sp., holotype male (USNM 1072201): a, frontal region, dorsal view; b, same, lateral view; c, rostrum, dorsal view; d, antennule, lateral view; e, antenna, ventral view; f, same, scaphocerite, dorsal view; $g$, posterior margin of carapace; h, first pleopod; i, second pleopod; j, same, detail of appendix masculina and appendix interna; $k$, sixth abdominal segment, lateral view; l, same, preanal plate, ventral view; m, uropod; n, same, distal portion of exopod; o, telson, dorsal view. Scales: $1 \mathrm{~mm}$. 


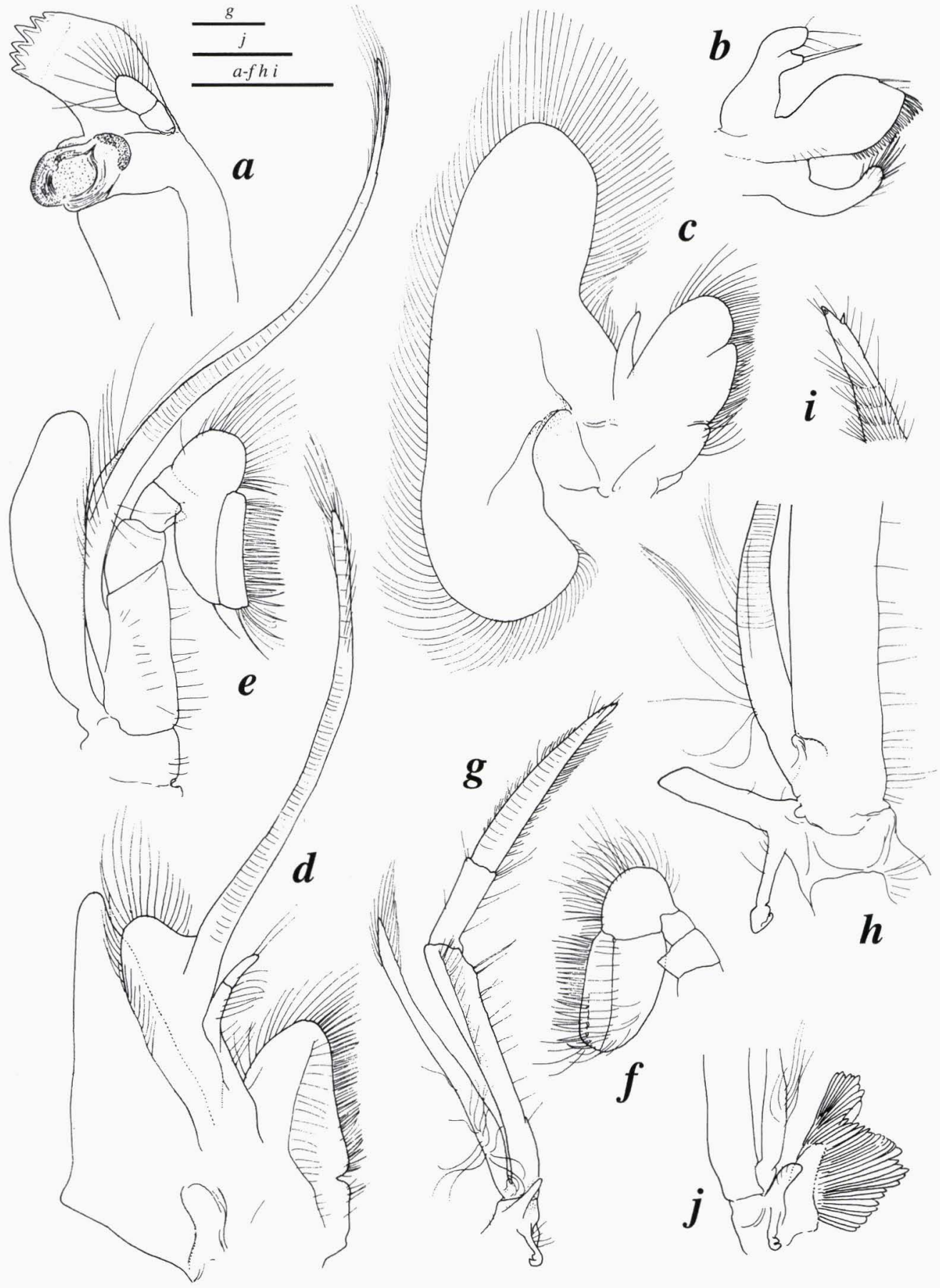

Fig. 3. Coutieralpheus setirostris, n. gen., n. sp., holotype male (USNM 1072201): a, mandible; b, maxillule; c, maxilla; d, first maxilliped; e, second maxilliped; f, same, distal portion of endopod, mesial view; g, third maxilliped (arthrobranch not drawn); h, same, basal portion (arthrobranch not drawn); i, same, distal portion; j, same, detail of arthrobranch. Scales: $1 \mathrm{~mm}$. 


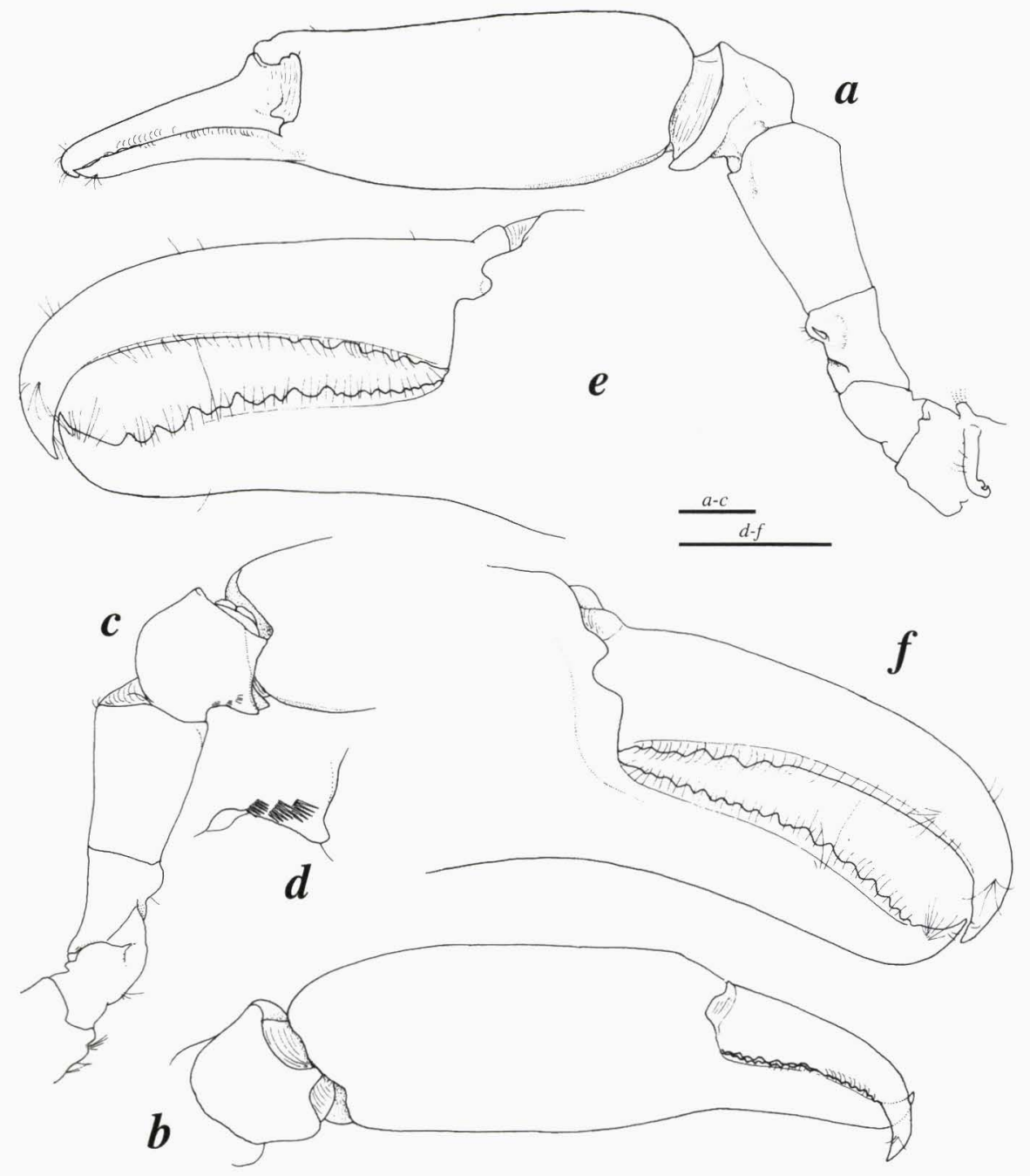

Fig. 4. Coutieralpheus setirostris, n. gen., n. sp., holotype male (USNM 1072201): a, left cheliped, lateral view; b, same, carpus and chela, mesial view; c, same, ischium, merus and carpus, mesial view; $d$, detail of setal rows on carpus; e, same, fingers of chela; $f$, right cheliped, fingers of chela. Scales: $1 \mathrm{~mm}$.

phyletic genus (Anker, pers. obs.). Parabetaeus, as redefined by Nomura \& Anker (2000), appears to be closely related to some species within Alpheopsis (s. lat.). Coutieralpheus differs from both Alpheopsis (s. lat). and from Parabetaeus in the following characteristics: (1) elongate lateral plate on the coxa of the third maxilliped (not elongate in Alpheopsis and Parabetaeus); (2) carapace with a distinct anterolateral suture (absent in Alpheopsis and Parabetaeus); (3) rostrum bearing distally two thickened setae (absent in Alpheopsis and Parabetaeus); (4) carpus of the chelipeds bearing mesial rows of setae (lacking in Alpheopsis and Parabetaeus); (5) short and stout stylocerite, barely reaching the distal margin of the first article of the antennular peduncle (vs. much longer, reaching at least to the middle of the second article or to the third article in Alpheopsis and Parabetaeus); (6) expanded caridean lobe and elongate epipod on the first and second maxillipeds, respectively (caridean lobe not expanded, epipod not 

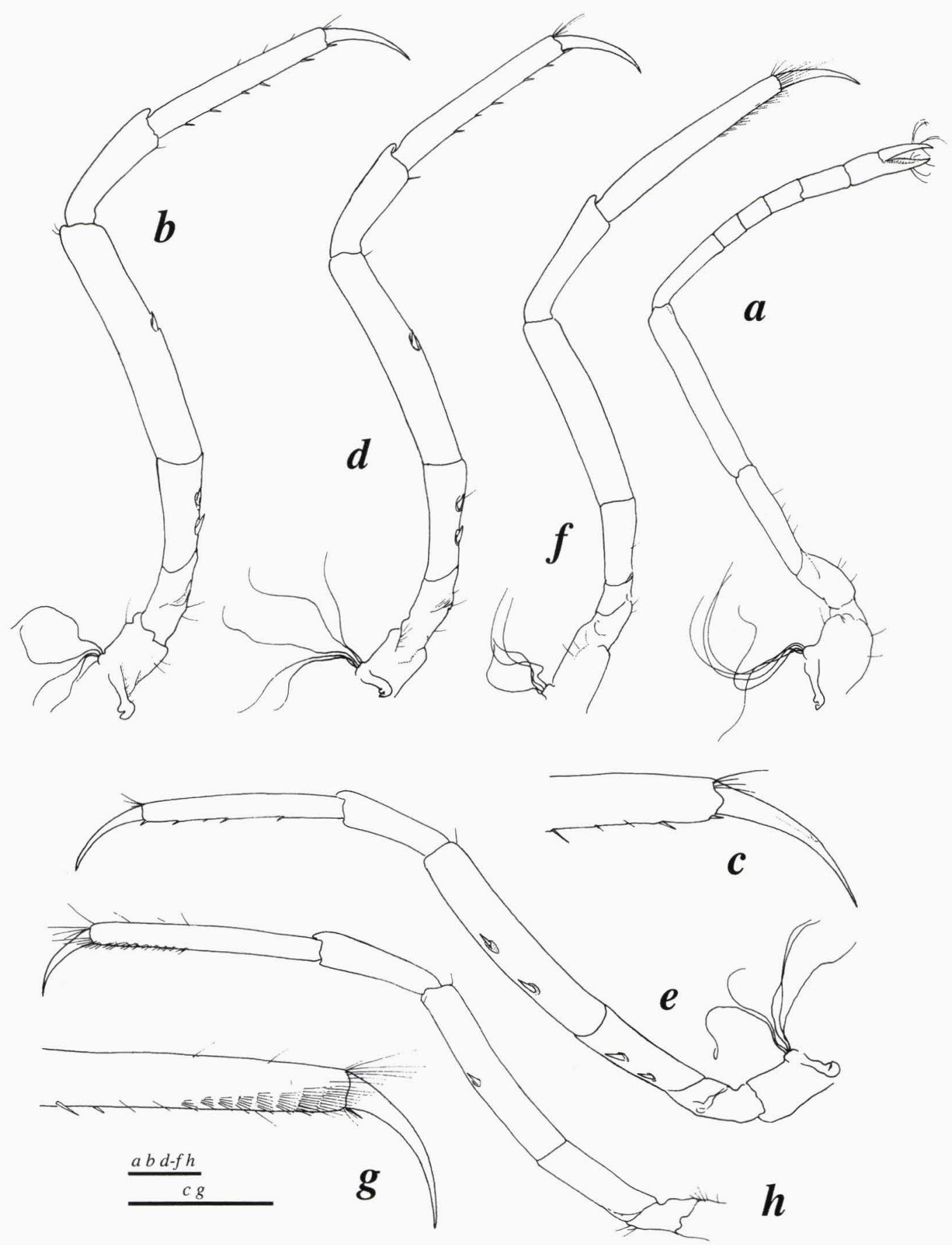

Fig. 5. Coutieralpheus setirostris, n. gen., n. sp., holotype male (USNM 1072201): a, right second pereiopod; b, right third pereiopod; c, same, distal propodus and dactylus; d, right fourth pereiopod; e, left fourth pereiopod; f, right fifth pereiopod; $g$, same, distal propodus and dactylus; h, left fifth pereiopod. Scales: $1 \mathrm{~mm}$. 

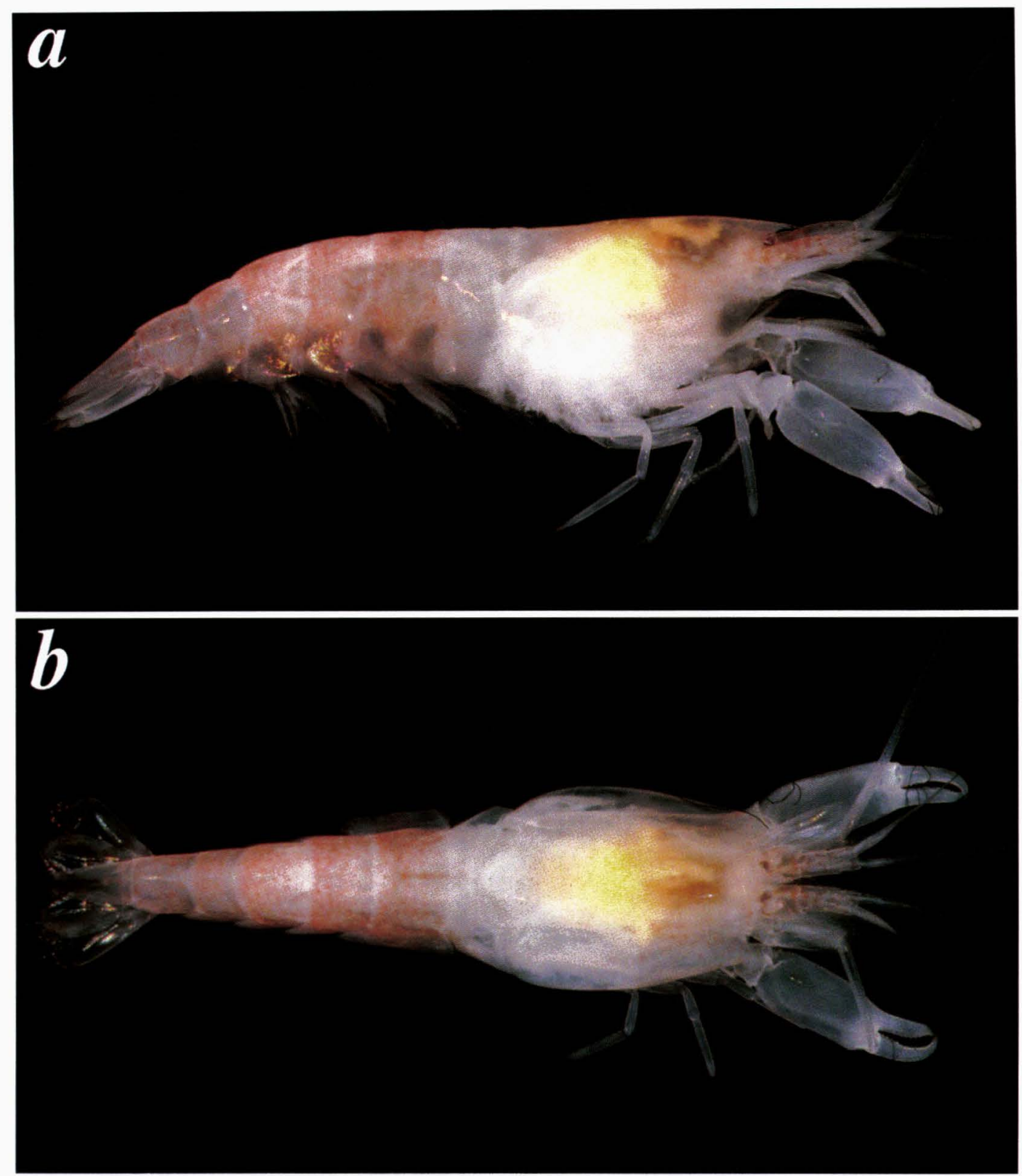

Fig. 6. Coutieralpheus setirostris, n. gen., n. sp., post-moult holotype male prior to preservation (USNM 1072201): a, lateral view; $b$, dorsal view (photographs by DLF).

elongate in Alpheopsis and Parabetaeus); and (7) ischium of the cheliped bearing small ventrolateral spine (absent in Alpheopsis and Parabetaeus). The new genus can be separated from Parabetaeus by at least three further features: (1) rounded posterior margin of the telson (vs. with median triangular protru- sion in Parabetaeus); (2) frontal margin bearing broadly triangular rostrum and lacking orbital teeth (vs. without or with small blunt rostrum, and with more or less developed extra-corneal teeth in Parabetaeus); and (3) chelipeds stout and carried extended (vs. more slender and capable of flexion due to 
the ventral flattening or depression of the merus in Parabetaeus). The chelipeds of Coutieralpheus setirostris are superficially similar to the chelipeds of several species of Alpheopsis. However, all species of Alpheopsis with non-sculptured chelipeds have spines on the dorsal margin of the ischium of the chelipeds; these spines are lacking in Coutieralpheus setirostris. From the preceding morphological comparisons, it appears that Coutieralpheus is not closely related to any other alpheid genus, with the possible exception of Deioneus.

\section{Acknowledgements}

We owe a tremendous debt to the late Raymond B. Manning of the National Museum of Natural History, Smithsonian Institution, for his leadership in studies of the Indian River Lagoon infaunal decapods. As in the present paper, the materials that he collected, independently and in collaboration with one of us (DLF), will continue to advance our understanding of decapod diversity in this region for many years to come. We are also grateful to Mary E. Rice and Valerie Paul (former and present station directors, respectively) for their continued support of research efforts by DLF based at the Smithsonian Marine Laboratory, Fort Pierce, both through small grants and provision of access to facilities. Additional support for this study was provided under US National Science Foundation grant no. DEB0315995 to DLF. We are also indebted to A. Richard Palmer (Department of Biological Sciences, University of Alberta, Edmonton) for the financial support from his NSERC operating grant (A7245), enabling AA to travel to Lafayette in November 2003. This is contribution number 611 from the Smithsonian Marine Station, Fort Pierce, and contribution number 105 from the University of Louisiana Laboratory for Crustacean Research.

\section{Literature Cited}

Abed-Navandi, D., 2000. Thalassinideans new to the fauna of Bermuda and the Cape Verde Islands. Annalen des Naturhistorischen Museums in Wien, 102B: 291-299.

Anker, A., 2003a. Alpheid shrimps from the mangroves and mudflats of Singapore. Part I. Genera Salmoneus, Athanas and Potamalpheops, with the description of two new species (Crustacea: Decapoda: Caridea). Raffles Bulletin of Zoology, 51: 283-314.

,$- 2003 \mathrm{~b}$. New records of Salmoneus Holthuis, 1955 (Crustacea: Decapoda: Alpheidae) from northern Australia, with description of one new species and remarks on S. serratidigitus Coutière, (1896). The Beagle, 19: 101-109.

- Jeng, M.-S., \& Chan, T. Y., 2001. Two unusual species of Alpheidae (Decapoda: Caridea), associated with upogebiid mudshrimps in the mudflats of Taiwan and Vietnam. Journal of Crustacean Biology, 21: 1049-1061.

Banner, D. M., \& Banner, A. H. , 1973. The alpheid shrimp of Australia, part I: the lower genera. Records of the Australian Museum, 28: 291-382.

Berggren, M., 1991. Athanopsis rubricinctuta, new species (Decapoda: Natantia: Alpheidae), a shrimp associated with an echiuroid at Inhaca Island, Moçambique. Journal of Crustacean Biology, 11: 166-178.

Branch, G. M., Griffith, C. L., Branch, M. L., \& Beckley, L. E., 1994, Two Oceans-a Guide to the Marine Life of Southern Africa. 360 pp. David Philip Publishers (Pty) Ltd, Claremont, South Africa.

Chace, F. A. Jr., 1988. The caridean shrimps (Crustacea: Decapoda) of the Albatross Philippine Expedition, 1907-1910, part 5 : Family Alpheidae. Smithsonian Contributions to Zoology, 466 : i-v + 1-99.

\& Abbott, D. P. 1980. Caridea: The Shrimps. Chapter 23. In: R.H. Morris, D.P. Abbott, \& E.C. Haderlie (eds.), Intertidal Invertebrates of California. Stanford University Press, Stanford, California, U.S.A. 567-756.

Carvacho, A., 1989. Sur l'appendix masculina chez Salmoneus (Decapoda, Crustacea). Crustaceana, 57: 253-256.

Coutière, H., 1899. Les "Alpheidae", morphologie externe et interne, formes larvaires, bionomie. Annales des Sciences Naturelles, Zoologie, série 8, 9: 1-560, pls. 1-6. Masson et 
Cie éditions, Paris, France.

Dawson, C. E., 1967. Notice of the occurrence of alpheid shrimp Leptalpheus forceps Williams in the northern Gulf of Mexico. Crustaceana, 12: 224.

De Grave, S., \& Anker, A., 2000. A new genus and new species of alpheid shrimp (Crustacea: Decapoda) from Papua New Guinea. Raffles Bulletin of Zoology, 48: 249-256.

—, \& Wilkins, H. K. A., 1997. A new record of Salmoneus rostratus Barnard, 1962 (Decapoda, Alpheidae) from Hansa Bay, Papua New Guinea). Crustaceana, 70: 633-636.

Dworschak, P. C., Anker, A., \& Abed-Navandi, D., 2000. A new genus and three new species of alpheids (Decapoda: Caridea) associated with thalassinids. Annalen des Naturhistorischen Museums in Wien, 102B: 301-320.

Dworschak, P.C. \& Coelho, V. R. 1999. On two alpheids from Araça (Sao Paulo, Brazil) with a description of a new species of Leptalpheus (Decapoda: Caridea: Alpheidae). Annalen des Naturhistorischen Museums in Wien, 101B: 475-488.

Felder, D. L., \& Manning, R. B., 1986. A new genus and two new species of alpheid shrimps (Decapoda: Caridea) from south Florida. Journal of Crustacean Biology, 6: 497-508.

—_ \& Manning, R. B., 1997. Associations, adaptations and diversity in commensal alpheoid shrimp of the genus Leptalpheus Williams, 1965. Program, The Crustacean Society 1997 Summer Meeting, 21-24 May 1997, Mobile, Alabama: 17-18.

—, Manning, R. B., \& Lemaitre, R., 1995. Ecological and biogeographical implications of distributions in mangrove-associated thalassinidean and alpheoid shrimp (Decapoda). American Zoologist, 35: 14A.

—, Nates S. F., \& Robles, R. R., 2003. Hurricane Mitch: Impacts of bioturbating crustaceans in shrimp ponds and adjacent estuaries of coastal Nicaragua. Open File Report, 03-179: 1-70.

Froglia, C., \& Atkinson R. J. A., 1998. Association between Athanas amazone (Decapoda: Alpheidae) and Squilla mantis (Stomatopoda: Squillidae). Journal of Crustacean Biology, 18: 529-532.

Hart, J. F. L., 1964. Shrimps of the genus Betaeus on the Pacific coast of North America with descriptions of three new species. Proceedings of the United States National Museum, 115: 431-466.

Hayashi, K.-I., 1998. A new genus and a new species of alpheid shrimp (Decapoda, Caridea) from Japan. Zoosystema, 20: 229-238.

- 2002. A new species of the genus Athanas (Decapoda, Caridea, Alpheidae) living in the burrows of a mantis shrimp. Crustaceana, 75 : 395-403.

Manning, R. B., 1975. Two methods for collecting crustaceans in shallow water. Crustaceana, 29: 317-319.

Miya, Y., 1980. Two new records of the genera, Athanopsis and Prionalpheus, from Japan, with description of a new species (Crustacea, Decapoda, Alpheidae). Publications from the Amakusa Marine Biological Laboratory, Kyushu University, 5: 117-131.

- 1984 . Alpheid shrimps from the Truk, Ponape and Majuro Atolls (Crustacea Decapoda). Proceedings of the Japanese Society of Systematic Zoology, Tokyo, 27: 67-100.

Nomura, K., 2000. Host and colour variation of Alpheus barbatus Coutière (Crustacea, Alpheidae) in Japan. Biological Magazine of Okinawa, 38: 59-64. (in Japanese)

- \& Anker, A., 2001. Redescription of Parabetaeus culliereti Coutière and status of the genus Neoalpheopsis Banner (Decapoda: Caridea: Alpheidae). Crustacean Research, 30: 43-54.

Saloman, C. H., 1971. The shrimp Leptalpheus forceps in Old Tampa Bay, Florida. Quarterly Journal of Florida Academy of Sciences, 34: 66-67.

Schmitt, W. L., 1926. The macruran, anomuran, and stomatopod Crustaceans collected by the American Museum Congo Expedition, 19091915. With field notes by Herbert Lang and James P. Chapin. Bulletin of the American Museum of Natural History, 53: 1-67, pls. 1-9.

Silliman, B. R., Layman, C. A., \& Altieri, A. H., 2003. Symbiosis between an alpheid shrimp and a xanthoid crab in salt marshes of midAtlantic States, U.S.A. Journal of Crustacean Biology, 23: 876-879.

Williams, A. B., 1965. A new genus and species of snapping shrimp (Decapoda, Alpheidae) from the southeastern United States. Crustaceana, 9: 192-198.

Addresses: (AA) Smithsonian Tropical Research Institute, Naos Unit 0948 APO AA 34002, U.S.A; (DLF) Department of Biology, University of Louisiana, Lafayette, LA, 705042451, U.S.A.

Emails: (AA) ankera@si.edu; dlf4517@louisiana.edu
(DLF) 